\title{
Copper metabolism in retinitis pigmentosa patients
}

\author{
SUNKARA SANGAMESWAR RAO,${ }^{1}$ MADHUSUDAN SATAPATHY, ${ }^{2}$ \\ AND ARI SITARAMAYYA ${ }^{1}$ \\ From the ${ }^{1}$ Institute of Genetics, Osmania University, and ${ }^{2}$ Sarojini Devi Eye Hospital, \\ Hyderabad, Andhra Pradesh, India
}

SUMMARY Serum copper, ceruloplasmin, and urinary copper were estimated in 13 normal subjects and 24 patients with primary retinitis pigmentosa. The serum copper levels in patients appeared to be higher and ceruloplasmin levels lower than in the normal subjects. The patients seem to fall into 2 categories with regard to urinary copper. About a third of them excreted 2-4 times more copper in the urine, while in the others the excretion is comparable to normal subjects. It appears possible that there exists in India a genetic isolate of retinitis pigmentosa with altered copper metabolism. The distribution of these patients may be different between the northern and southern parts of the country.

Retinitis pigmentosa (tapetoretinal degeneration or retinal abiotrophy) is a disease whose aetiology is not yet known. Retinal degeneration occurs secondarily in such disorders like abetalipoproteinaemia, Refsum's disease, and others. Rocha and Antunes ${ }^{1}$ suggested that primary retinitis pigmentosa may be an autoimmune disease. Gouras and Chader ${ }^{2}$ proposed a possible role for retinol binding protein in retinitis pigmentosa. Gahlot et al. ${ }^{3}$ suggested that the primary defect in retinitis pigmentosa is in copper metabolism. They reported decreased serum ceruloplasmin and increased urinary copper excretion in every patient they examined. ${ }^{34}$ Investigators in the United States ${ }^{5}$ and Denmark ${ }^{6}$ who have conducted similar studies of copper metabolism on retinitis pigmentosa patients found no abnormalities in copper metabolism similar to those found by Gahlot et al. Discussing their results, Marmor et al. ${ }^{5}$ considered it possible that Gahlot et al. from India were studying a genetic isolate of retinitis pigmentosa patients in whom copper metabolism is altered. We considered it worth while to investigate copper metabolism in retinitis pigmentosa patients, and we report here that about a third of all patients we investigated showed abnormalities of copper metabolism of the nature described by Gahlot et al.

\section{Subjects and methods}

The patients in this study visited the Retinal Services Section of Sarojini Devi Eye Hospital between 19 March and 20 July 1980 . To avoid bias every patient

Correspondence to $\mathrm{Dr} A$. Sitaramayya, University of Pennsylvania School of Medicine, Department of Anaiomy G3, Philadelphia, PA 19174, USA. diagnosed as suffering from primary retinitis pigmentosa was included in this study. They were all informed of the nature of the study. The normal subjects were the surgeons at Sarojini Devi Eye Hospital and the staff of the Institute of Genetics and their family members.

After the diagnosis had been made and it was established that the patients suffered from no other disease the following 3 parameters were measured on these patients: (1) serum copper was measured by the method of Giorgio et al. ${ }^{7}$; (2) ceruloplasmin concentration in serum was measured from the rate of oxidation of $p$-phenylenediamine as described by Henry et al. ${ }^{8}$; (3) copper content in $24 \mathrm{~h}$ urine samples was measured by the method of Giorgio et al. ${ }^{7}$ The same parameters were measured in normal subjects by the same methods.

\section{Results}

Serum copper and ceruloplasmin concentrations and urinary excretion of copper for 13 normal subjects are shown in Table 1 . The values for 24 patients are shown in Table 2. (SI conversion: ceruloplasmin $\mathrm{mg} / \mathrm{l}=\mathrm{mg} / 100 \mathrm{ml} \times 10$; serum copper $\mu \mathrm{mol} / \mathrm{l}=\mu \mathrm{g} / 100 \mathrm{ml} \times 0 \cdot 157$; urinary copper $\mu \mathrm{mol} / 24 \mathrm{~h}=\mu \mathrm{g} / 24 \mathrm{~h} \times 0.0157$.)

Serum copper in normal subjects varied from 67.5 to $150.0 \mu \mathrm{g}$ per $100 \mathrm{ml}$. The mean value was $102.4 \mu \mathrm{g}$. Values in the range of 64 to $143 \mu \mathrm{g}$ per $100 \mathrm{ml}$ for normal subjects were reported by Marmor et al. ${ }^{5}$ and in the range of 60 to $150 \mu \mathrm{g}$ per $100 \mathrm{ml}$ by Gahlot. ${ }^{4}$ The serum copper content of normal subjects in this study is comparable with values reported by these authors. In the patients the serum 
Table 1 Parameters of copper metabolism in control subjects

\begin{tabular}{|c|c|c|c|c|c|}
\hline $\begin{array}{l}\text { Serial } \\
\text { number }\end{array}$ & Sex & $\begin{array}{l}\text { Age } \\
\text { (years) }\end{array}$ & $\begin{array}{l}\text { Serum } \\
\text { copper } \\
\mu \mathrm{g} \mathrm{per} \\
100 \mathrm{ml}\end{array}$ & $\begin{array}{l}\text { Serum } \\
\text { ceruloplasmin, } \\
\text { mg per } \\
100 \mathrm{ml}\end{array}$ & $\begin{array}{l}\text { Urine } \\
\text { copper } \\
\text { in } 24 \text { hours } \\
\text { sample, } \mu g\end{array}$ \\
\hline 1 & $\mathbf{M}$ & 25 & $78 \cdot 7$ & $19 \cdot 80$ & $37 \cdot 7$ \\
\hline 2 & $\mathbf{M}$ & 34 & $105 \cdot 0$ & $21 \cdot 48$ & $25 \cdot 5$ \\
\hline 3 & $\mathbf{M}$ & 32 & 150.0 & $33 \cdot 50$ & $21 \cdot 7$ \\
\hline 4 & $\mathbf{M}$ & 34 & 120.0 & $28 \cdot 20$ & 43.4 \\
\hline 5 & $\mathbf{M}$ & 35 & $135 \cdot 0$ & $29 \cdot 76$ & 38.0 \\
\hline 6 & $\mathbf{M}$ & 52 & $90 \cdot 0$ & $69 \cdot 00$ & $40 \cdot 4$ \\
\hline 7 & $\mathbf{M}$ & 40 & $150 \cdot 0$ & $44 \cdot 28$ & $60 \cdot 2$ \\
\hline 8 & $F$ & 28 & 75.0 & 31.46 & 26.5 \\
\hline 9 & $\mathrm{~F}$ & 42 & $120 \cdot 0$ & 28.02 & $46 \cdot 2$ \\
\hline 10 & $\mathbf{M}$ & 18 & 75.0 & $21 \cdot 84$ & $29 \cdot 2$ \\
\hline 11 & $\mathbf{M}$ & 60 & $67 \cdot 5$ & $23 \cdot 52$ & $42 \cdot 7$ \\
\hline 12 & $\mathbf{F}$ & 50 & $78 \cdot 7$ & 26.04 & $23 \cdot 2$ \\
\hline 13 & $\mathbf{M}$ & 30 & $86 \cdot 2$ & $21 \cdot 72$ & 29.7 \\
\hline
\end{tabular}

For SI conversions see text.

Table 2 Parameters of copper metabolism in retinitis pigmentosa patients

\begin{tabular}{|c|c|c|c|c|c|}
\hline $\begin{array}{l}\text { Serial } \\
\text { number }\end{array}$ & Sex & $\begin{array}{l}\text { Age } \\
\text { (years) }\end{array}$ & $\begin{array}{l}\text { Serum } \\
\text { copper, } \\
\mu \mathrm{g} \mathrm{per} \\
100 \mathrm{ml}\end{array}$ & $\begin{array}{l}\text { Serum } \\
\text { ceruloplasmin } \\
\text { mg per } \\
100 \mathrm{ml}\end{array}$ & $\begin{array}{l}\text { Urine } \\
\text { copper } \\
\text { in } 24 \text { hours } \\
\text { sample, } \mu \text { g }\end{array}$ \\
\hline 1 & $F$ & 27 & 198.7 & $20 \cdot 58$ & 56.0 \\
\hline 2 & $\mathbf{M}$ & 15 & $206 \cdot 2$ & $18 \cdot 12$ & $47 \cdot 5$ \\
\hline 3 & $\mathbf{M}$ & 14 & 99.9 & $24 \cdot 60$ & $31 \cdot 4$ \\
\hline 4 & $\mathbf{M}$ & 32 & $83 \cdot 3$ & $23 \cdot 52$ & 30.0 \\
\hline 5 & $\mathbf{F}$ & 35 & $92 \cdot 4$ & $33 \cdot 36$ & $105 \cdot 0$ \\
\hline 6 & $\mathbf{F}$ & 34 & $103 \cdot 1$ & $19 \cdot 50$ & 165.9 \\
\hline 7 & $F$ & 20 & 125.0 & 18.00 & $149 \cdot 6$ \\
\hline 8 & $\mathbf{F}$ & 18 & $150 \cdot 0$ & $15 \cdot 54$ & 16.6 \\
\hline 9 & $\mathbf{F}$ & 14 & $172 \cdot 5$ & $19 \cdot 50$ & $168 \cdot 5$ \\
\hline 10 & $\mathbf{M}$ & 28 & $150 \cdot 0$ & $12 \cdot 12$ & 180.5 \\
\hline 11 & $F$ & 20 & $187 \cdot 5$ & $15 \cdot 60$ & $146 \cdot 3$ \\
\hline 12 & $\mathbf{M}$ & 20 & 112.5 & $18 \cdot 18$ & $47 \cdot 9$ \\
\hline 13 & $\mathbf{M}$ & 18 & $112 \cdot 5$ & 24.72 & $25 \cdot 6$ \\
\hline 14 & $\mathbf{F}$ & 19 & $75 \cdot 0$ & $25 \cdot 74$ & 40.6 \\
\hline 15 & $\mathbf{M}$ & 25 & 93.7 & 12.66 & $42 \cdot 0$ \\
\hline 16 & $F$ & 12 & $105 \cdot 0$ & 33.00 & 36.9 \\
\hline 17 & $\mathbf{M}$ & 13 & $90 \cdot 0$ & $30 \cdot 50$ & $34 \cdot 5$ \\
\hline 18 & $F$ & 16 & $120 \cdot 0$ & $27 \cdot 80$ & $20 \cdot 0$ \\
\hline 19 & $\mathbf{M}$ & 22 & $112 \cdot 5$ & $20 \cdot 52$ & $20 \cdot 5$ \\
\hline 20 & $\mathbf{M}$ & 17 & $135 \cdot 0$ & $22 \cdot 50$ & $97 \cdot 5$ \\
\hline 21 & $\mathbf{M}$ & 16 & $105 \cdot 0$ & $30 \cdot 72$ & $30 \cdot 5$ \\
\hline 22 & $\mathbf{M}$ & 38 & $120 \cdot 0$ & 34.98 & $175 \cdot 5$ \\
\hline 23 & $\mathbf{M}$ & 28 & $75 \cdot 0$ & $26 \cdot 10$ & $27 \cdot 4$ \\
\hline 24 & $\mathbf{M}$ & 15 & $75 \cdot 0$ & 30.96 & $53 \cdot 2$ \\
\hline
\end{tabular}

For SI conversions see text. copper varied from 75 to $206 \cdot 2 \mu \mathrm{g}$ per $100 \mathrm{ml}$, with a mean value of $135.7 \mu \mathrm{g}$. This value is considerably higher than the mean value for normal subjects and differs from that of Marmor et al., ${ }^{5}$ who found no major difference between control subjects and patients, and also from that of Gahlot, ${ }^{4}$ who found that the patients showed lower serum copper content compared with normal subjects.

The serum ceruloplasmin content, measured by the diamine oxidase activity, ranged from 19.8 to $69.0 \mathrm{mg}$ per $100 \mathrm{ml}$ with a mean value of $30.66 \mathrm{mg}$. The ceruloplasmin concentration in the patients is lower, with a mean value of $22.81 \mathrm{mg}$ per $100 \mathrm{ml}$ and a range of 12.12 to $34.98 \mathrm{mg}$. The mean value for ceruloplasmin in control subjects in the study of Marmor et al. ${ }^{5}$ was 32.3 and is close to the observation in this study. However, in their study the mean value in patients was higher at $37.0 \mathrm{mg}$ per $100 \mathrm{ml}$. Though the mean value for normal subjects reported by Gahlot $e t$ al. ${ }^{3}$ is much lower than in our observations, that the patients showed lower ceruloplasmin concentrations than normal subjects observed in this study is in agreement with the results of Gahlot et al. ${ }^{3}$ and Gahlot. ${ }^{4}$

The urinary excretion of copper in 24 hours in normal subjects ranged from $21 \cdot 7$ to $60 \cdot 2 \mu \mathrm{g}$ with a mean value of $35.7 \mu \mathrm{g}$. In the patients the range was $16.6 \mu \mathrm{g}$ to $180.5 \mu \mathrm{g}$, with a mean value of 79.5 , which is more than twice the average for normal subjects. The values for normal subjects in our study are in agreement with those reported by Gahlot ${ }^{4}$ and Marmor et al. ${ }^{5}$ However, while Marmor et al. found that patients excreted less than $50 \mu \mathrm{g}$ of copper in 24 hours, as did the normal subjects, Gahlot et al. ${ }^{3}$ and Gahlot ${ }^{4}$ reported that the urinary excretion of copper in patients was elevated to about $200 \mu \mathrm{g}$ per 24 hours. One striking difference between the present study and that of Gahlot is that, while only 8 out of 24 patients in our study showed urinary excretion of copper above $50 \mu \mathrm{g}$ in 24 hours, the latter reported that each one of their patients showed increased copper excretion in the urine. When we isolate these 8 cases in our study (patients $5-7,9-11,20$, and 22), their urinary copper excretion ranged from 97.5 to $180.5 \mu \mathrm{g} / 24$ hours, with a mean value of $148.6 \mu \mathrm{g}$ (Table 3 ). This value is close to the report of Gahlot. Also, when these 8 are excluded from the rest of the patients, the urinary excretion for these patients averaged $40.0 \mu \mathrm{g}$ and is comparable with that for control subjects. The 8 patients with increased urinary copper excretion and the rest of the patients had comparable ceruloplasmin concentrations (Table 3 ). The serum copper was raised in the rest of the patients but not to the same level as in the 8 patients with increased urinary copper excretion (Table 3 ). 
Table 3 Comparison of patients with raised urinary copper excretion with other patients and normal subjects

\begin{tabular}{llll}
\hline Subjects & $\begin{array}{l}\text { Serum } \\
\text { copper, } \\
\mu \mathrm{g} \mathrm{per} \\
100 \mathrm{ml}\end{array}$ & $\begin{array}{l}\text { Serum } \\
\text { ceruloplasmin, } \\
\text { mg per } \\
100 \mathrm{ml}\end{array}$ & $\begin{array}{l}\text { Copper in } \\
24 \text { hours } \\
\text { urine, } \mu \mathrm{g}\end{array}$ \\
\hline Control & 102.4 & 30.66 & 35.7 \\
$\begin{array}{l}\text { Patients with elevated } \\
\quad \text { urinary copper }\end{array}$ & 135.7 & 21.94 & 148.6 \\
$\quad$ excretion & 118.9 & 23.30 & 40.0 \\
\hline Other patients & & & \\
\hline
\end{tabular}

Data presented here are mean values. For SI conversions see text.

\section{Discussion}

From our observations it is evident that the serum copper levels in patients and normal subjects are not strikingly different, though the mean value for patients was higher than that for control subjects. However, the urinary excretion of copper is increased in 8 out of the 24 patients to about 4 times that of the control subjects, while in the rest of the patients the excretion is comparable to that of the control subjects. The mean value for serum ceruloplasmin levels in our control subjects agrees with the values reported, ${ }^{10}$ and individually each one of them fell in the reported range for normal subjects. The ceruloplasmin content in patients as a group is much lower than in controls, and 7 patients have ceruloplasmin content below the normal range. Three of these 7 are in the group excreting higher copper in urine.

The reports of Gahlot et al..$^{3}$ and Gahlot ${ }^{4}$ that each one of the retinitis pigmentosa patients they examined showed increased excretion of copper in urine and showed decreased ceruloplasmin in serum and the report of Marmor et al. ${ }^{5}$ and Ehlers and Bulow $^{6}$ that their patients showed no abnormal values of copper metabolism distinguishable from the normal subjects show the extent of controversy on this subject. However, the suggestion of Marmor et al. ${ }^{5}$ that there could be a genetic isolate of retinitis pigmentosa patients in India who either have a deranged copper metabolism or show such derangement under the influence of some external factors deserves serious consideration. The present observations reveal that 8 out of 24 patients showed signs of altered copper metabolism. It is hard to explain the difference between our results and those of Gahlot et $\mathrm{al}^{3}$ Of the 24 cases in our study 5 were Muslims, 17 were Hindus, and 2 were Christians. Of the 8 cases with increased urinary copper excretion 2 were Muslims and 6 were Hindus. From these observations it is clear that retinitis pigmentosa with altered copper metabolism is not confined to any particular religious group (though we did have only two Christian patients). Regionally, 23 of our 24 patients were from the southern state of Andhra Pradesh (AP) and 1 (patient 5) was from Uttar Pradesh (UP) in North India. Seven of the patients from AP and the patient from UP showed elevated copper excretion in urine. It is interesting that our only patient from the northern part of India had an increased excretion of urinary copper, and it is noteworthy that only about a third of our patients showed altered copper metabolism in contrast to every patient in the study of Gahlot from northern India. ${ }^{4}$ If we consider that there is a genetic isolate of retinitis pigmentosa patients in India, this group constituted only a third of the population in the southern part of this country. More studies from the north as well as south will be useful in determining this distribution.

The dietary copper is absorbed from the intestine and transported to the liver mainly bound to albumin. There copper is incorporated into ceruloplasmin and released into the blood stream. The ceruloplasmin-bound copper represents about $90 \%$ of the total serum copper. Urinary excretion of copper is minimal, while the major mode of excretion is through faeces. However, in Wilson's disease, where copper accumulates in tissues, the ceruloplasmin content of serum drops to below $10 \mathrm{mg}$ per $100 \mathrm{ml}$ in about $80 \%$ of the patients, and the urinary copper excretion is often as high as $1000 \mu \mathrm{g}$ or more per day.11 Wilson's disease is treated with decoppering agents like D-penicillamine. Gahlot ${ }^{4}$ reported treatment of retinitis pigmentosa patients with a decoppering agent and low copper diet and suggested that both acuity and fields of vision improved after a few months of treatment. We feel that the decrease in ceruloplasmin concentration and the rise in urinary copper in the 8 patients we isolated are not comparable in severity to those of Wilson's disease to warrant treatment with decoppering agents. We are advising low copper diet therapy to these 8 patients to see if that alone brings about the desired improvements.

The authors thank the staff at the Institute of Genetics and Sarojini Devi Eye Hospital for their excellent co-operation extended during this study. The Department of Science and Technology, Government of India, provided generous funds to the Institute of Genetics. We thank Drs P. Venkateswar Rao, O. S. Reddi, C. S. R. Sharma, and P. Siva Reddy for discussions.

\section{References}

1 Rocha H, Antunes L. Primary retinitis pigmentosaautoimmunity? Metabol Ophthalmol 1977; 1: 153-6.

2 Gouras P, Chadar G. Retinitis pigmentosa and retinol binding protein. Invest Ophthalmol Visual Sci 1974; 13: 239-42.

3 Gahlot DK, Khosla PK, Makashir PD, Vasuki K, 
Basu N. Copper metabolism in retinitis pigmentosa. Br J Ophthalmol 1976; 60: 770-4.

4 Gahlot DK. Retinitis pigmentosa-a state of copper toxicity? Indian J Ophthalmol 1979; 27: 170-3.

5 Marmor MF, Nelson JW, Levin AS. Copper metabolism in American retinitis pigmentosa patients. $\mathrm{Br} J$ Ophthalmol 1978; 62: 168-71.

6 Ehlers N, Bulow N. Clinical copper metabolism parameters in patients with retinitis pigmentosa and tapetoretinal degenerations. Br J Ophthalmol 1977; 61: 595-6.

7 Giorgio AJ, Cartwright GE, Wintrobe MM. Determination of urinary copper by means of direct extraction with zinc dibenzyldithiocarbamate. Am $J$ Clin Pathol $1964 ; 41$ : 22-6.

8 Henry RJ, Chiamori N, Jacobs SL, Segalove M. Determination of ceruloplasmin oxidase in serum. Proc Soc Exp Biol Med 1960; 104: 620-4.

9 Lewis KO. The nature and excretion of biliary copper in man. Clin Sci 1973; 45: 133.

10 Gollan JL. Reply to Lewis, 1973. Clin Sci 1973;45: 133-4.

11 Sass-Kortsak A, Bearn AG. Hereditary disorders of copper metabolism. In: Stanbury JB, Wyngaarden JB, Fredrickson DS, eds. The Metabolic Basis of Inherited Disease. New York: McGraw-Hill, 1978: 1098-126. 